\title{
WPS3557
}

\section{Foreign Aid and Market-Liberalizing Reform}

\author{
Jac Heckelman* \\ Stephen Knack**
}

World Bank Policy Research Working Paper 3557, April 2005

The Policy Research Working Paper Series disseminates the findings of work in progress to encourage the exchange of ideas about development issues. An objective of the series is to get the findings out quickly, even if the presentations are less than fully polished. The papers carry the names of the authors and should be cited accordingly. The findings, interpretations, and conclusions expressed in this paper are entirely those of the authors. They do not necessarily represent the view of the World Bank, its Executive Directors, or the countries they represent. Policy Research Working Papers are available online at http://econ.worldbank.org.

*Wake Forest University, PO Box 7505, Winston-Salem NC 27109 (heckeljc @wfu.edu).

**The World Bank, 1818 H St. NW, Washington DC 20433 USA (sknack@ worldbank.org). 


\begin{abstract}
Market-oriented economic policies-reflected in limited economic activity by government, protection of private property rights, a sound monetary policy, outward orientation regarding trade and efficient tax and regulatory policy—have been strongly linked to faster rates of economic growth. Foreign aid is often provided in the belief that it encourages liberalizing reforms in these areas. This paper analyzes the impact of aid on market-liberalizing policy reform, correcting for the possible endogeneity of aid. Results indicate that higher aid slowed reform over the 1980-2000 period, as measured by a broad index of policies. Disaggregating policy into five areas, aid is significantly linked to slower reform in some policy areas but not in others. Disaggregating by decade, aid's adverse impact on policy reform is much more pronounced for the 1980s than for the 1990s.
\end{abstract}

JEL: O10, O19 


\section{Introduction}

Foreign aid often is intended by donors to improve the policy environment for private sector development in recipient nations by encouraging market liberalization. Several authors have argued, however, that aid can perversely delay or even reverse policy reform (e.g. Rodrik, 1996; Kapur and Webb, 2000). This study attempts to provide a more comprehensive test of aid's policy impact, using summary measures of market-oriented economic policies and institutions. Donors' aid allocations may intentionally favor recipients with better (or improving) policies and institutions. Alternatively, donors may respond to economic or humanitarian crises, produced or aggravated by poor policies, by increasing aid flows. Our tests therefore correct for the likely endogeneity of aid. Results indicate that aid on balance significantly retards rather than encourages market-oriented policy reform over the 1980-2000 period.

Disaggregating economic freedom into five broad policy areas, we find aid slows reform in some areas but not in others. Disaggregating by decade, we find the negative effects of aid are much stronger in the 1980s than in the 1990s.

Section 2 of the paper briefly establishes the importance of market-oriented policies and institutions, by reviewing evidence on their links to growth. Section 3 summarizes arguments and evidence on the effect of foreign aid on policy reform. Section 4 describes the data used in the empirical analysis, with results presented in section 5. Implications of our findings are discussed in section 6.

\section{Market Liberalization and Growth}

Various studies have analyzed the growth effects of selected aspects of marketoriented public policies, including the security of property rights (e.g. Knack and Keefer, 1995; Claessens and Laeven, 2003), openness to trade (Sachs and Warner, 1995; Frankel and Romer, 2000), low inflation (Fischer, 1993; Barro, 1997), government expenditures and debt (Barro, 1991; Easterly and Rebelo, 1993), and labor and product market regulation (Loayza, Oviedo and Serven, 2005). Multi-dimensional indicators of marketoriented policies have been used in other growth studies, such as Burnside and Dollar (2000), who construct a policy index from data on the budget surplus, inflation, and the Sachs-Warner openness dummy.

An even broader index of market-oriented policy, developed by the Fraser

Institute (Gwartney and Lawson, 2004), has been used extensively in empirical studies of 
growth. Fraser's "economic freedom" index ${ }^{1}$ is based on numerous specific policy indicators, which are grouped into several categories, and weighted to create an overall index value. Over time, the index has been updated by including additional countries and components, re-arranging category groupings, altering weights, and relaxing its former exclusion of subjective measures. A recent comprehensive review by Berggren (2003) finds with one exception (Heckelman and Stroup 2000) that each of 18 studies shows a positive relationship between the Fraser index (measured in changes and/or levels) and national rates of income growth. These studies have used different versions of the index, as well as different samples and statistical techniques, so the consistency of findings suggests the result to be robust. Each of the studies considered by Berggren, with again only one exception (Goldsmith 1997), included both developed and developing nations in their samples.

While these studies suggest that market-oriented policy, broadly defined and measured, is conducive to growth, some of these same studies find that not all of the different measures comprising the Fraser index have significant effects on growth. Using the original set of 14 freedom components for 1980, Heckelman and Stroup (2000) find only four of the components to be positive and statistically significant (at the $10 \%$ level) in a series of bivariate regressions for growth over the following ten-year interval. Moreover, only one of these four components, and one additional component, is positive and statistically significant in a regression including multiple components. Another component was found to be negative and statistically significant for growth, in both bivariate and multivariate regressions. Ayal and Karras (1998) report the average value for eight components from 1975-1990 to be significantly and positively correlated with growth during the same time interval, and only one of these components loses its significance when controlling for ending year GDP, population, and investment to GDP ratio. $^{2}$

The identical time intervals for the economic freedom values and growth period in Ayal and Karras (1998) make it difficult to determine the avenue of causation. A similar problem plagues the study by Carlsson and Lundström (2002), who use a more recent iteration of the Fraser index. They find that only two of the seven categories used to

\footnotetext{
${ }^{1}$ The term "economic freedom" suggests a libertarian philosophy; the Cato Institute is a co-publisher of the Fraser Institute's reports on economic freedom, and Milton Friedman has been a long-term advisor on the project. However, the content of the index closely matches the "Washington Consensus" set of marketoriented policy prescriptions often associated with the World Bank, International Monetary Fund, and the U.S. Treasury Department's Office of International Affairs. See Williamson (2000). The policy areas and measures covered by the Fraser index also overlap largely with the classifications and measures of "marketoriented reforms" in Loayza and Soto (2003).

${ }^{2}$ One of the original components is not included in their analysis, but no explanation is given for its absence.
} 
construct this index are robustly positively related to growth, while two other categories are robustly negatively related to growth. Again, the overlapping nature of their sample periods of 1970 to 1990 for average freedom values and 1975 to 1995 for the growth period make determining causality a problem. ${ }^{3}$ While Dawson (2003) finds that this version of the Fraser index Granger-causes growth, he concludes that only two of the categories can be said to Granger-cause growth, one of the categories is jointly determined with growth, and another is Granger-caused by growth.

Collectively, these studies indicate that economic freedom, broadly defined and measured, contributes importantly to growth. A major objective of foreign aid is to encourage market-oriented reforms that encourage growth. In contrast to the literature on market-oriented policies and growth, evidence on the impact of aid on policies is relatively sparse. The remainder of this paper investigates this question using the Fraser index, and taking into account the finding from the growth studies using this index that some policy areas may matter more than others.

\section{Aid and Market-Oriented Policy Reform}

Aid can affect policies in several ways. First, aid relationships typically create opportunities for donor staff to offer policy advice, either informally or in the form of technical cooperation. ${ }^{4}$ Although knowledge of the theoretical and empirical arguments for market-oriented policies are non-excludable public goods, aid relationships are nevertheless likely to increase the exposure of government officials in developing countries to this knowledge. Moreover, detailed policy advice and technical assistance are often required to help apply this knowledge, e.g. in the case of legal and judicial reform.

Second, in recent years some donors have allocated aid on the principle of selectivity, i.e. favoring recipients which have already achieved a more favorable policy environment for growth. Most notably, the World Bank's International Development Association (IDA) lends about $\$ 7$ billion per year to its poorest members on highly concessionary terms, with allocations based in large part on the Bank's assessments of the quality of policies and public sector management. The U.S. Millenium Challenge Account similarly is based on a system for assessing the policies and institutions of poor countries, with the aim of directing aid to governments that "rule justly, invest in their

\footnotetext{
${ }^{3}$ Although they were able to reject endogeneity of the economic freedom index using a Hausman test, they did not conduct similar tests on any of the separate categories comprising the index.

4 "Virtually all planned [World] Bank country operations" including investment projects, diagnostic studies, etc. as well as adjustment lending "have policy reform objectives" (World Bank, 2004: 10).
} 
people, and encourage economic freedom." ${ }^{5}$ Selectivity of this sort can increase the incentives of developing-country governments to implement market-oriented reforms, in order to increase their aid allocations. The prospect of increased aid encourages reform, resulting in actual aid increases.

A more traditional approach often associated with the international financial institutions (IFIs) is policy conditionality, often attached to "structural adjustment" loans. A consensus has emerged in recent years that conditionality of this type has been ineffectual (Easterly, 2005; Kapur and Webb, 2000; World Bank, 1998; Collier, 1997). If countries have to be bribed to reform in the first place, they have every incentive to implement the reforms to the minimum extent necessary to gain release of funds, and then to reverse the reforms - with the possibility of promising these same reforms again in the future in exchange for additional aid. In one frequently-cited example: "during a 15-year period, the Government of Kenya sold the same agricultural reform to the World Bank four times, each time reversing it after receipt of the aid" (Collier, 1997: 60 [italics in original]). In another, the IMF and World Bank made 22 loans to Pakistan between 1970 and 1997 tied to budget deficit reductions, which repeatedly failed to materialize (Mallaby, 2004: 182). Several recent World Bank and IMF studies have concluded that policy reform is driven primarily by domestic political economy considerations, and that conditionality is likely to be effective only in the early stages of reform, when it can bolster the position of reform advocates in government (World Bank, 2004; Devarajan, Dollar and Holmgren, 2001: ch. 1; Ivanova et al., 2003).

Often, the logic of adjustment lending is that recipient governments can use aid funds to compensate politically-powerful groups who would suffer, at least in the short run, from policy and institutional reforms. Aid can in effect purchase their acquiescence to liberalizing reforms, increasing the survival probability of reform-minded governments. However, aid can also help non-reforming governments survive, by reducing the cost of not reforming (Rodrik, 1996; Hsieh, 2000). By providing an alternative source of revenue, aid can relieve pressure on recipient governments to establish the efficient policies and institutions necessary for attracting private capital (Devarajan, Dollar and Holmgren, 2001: ch. 1). The end of U.S. aid - which had been generous in the 1950s - is often credited for the Korean and Taiwanese reforms of the 1960s (e.g. Rodrik, 1996; Brautigam, 2000).

\footnotetext{
${ }^{5}$ See www.mca.gov. The study by Burnside and Dollar (2000), concluding that aid contributes to growth only in good policy environments, is often cited as justification for allocating aid in this way. Easterly, Levine and Roodman (2004) however find that the Burnside-Dollar result is not robust in tests that include newly-available data for a few additional countries and years.
} 
Aid can have other unintended, adverse effects on economic policy and public sector management. Friedman (1958) has argued that because most aid goes to governments, it tends "to strengthen the role of the government sector in general economic activity relative to the private sector." Aid is commonly used for patronage purposes, by subsidizing employment in the public sector, or in state-operated enterprises, as foreign aid can provide funds for government to undertake investments that would otherwise be made by private investors. In Tanzania, for example, large and rising aid levels in the 1970s and 1980s helped sustain large government subsidies to state-owned enterprises and parastatals.

As high aid levels increase the rents available to those controlling the government, resources devoted to obtaining political influence increase; thus a "pervasive consequence of aid has been to promote or exacerbate the politicization of life in aidreceiving countries" (Bauer, 1984: 38). In extreme cases, aid may even encourage coup attempts and political instability, by making control of the gove rnment and aid receipts a more valuable prize (Grossman, 1992), with adverse effects for the security of property rights.

Although any negative effects of aid on policies are usually unintended by donors, there are some exceptions. Collier (1997) criticizes the IMF and other donors for insisting in some cases that aid recipients increase their tax revenues, often producing increases in trade taxes and other distortionary forms of mobilizing revenue in countries where the tax base is narrow and administrative capacity is weak.

Previous empirical literature does not provide a clear answer on whether the positive effects of aid on market-oriented policy reform outweigh any negative impacts. Burnside and Dollar (2000) find no relationship in their sample of 56 aid recipients between aid and their policy index. As cited in Collier (1997: 57), a World Bank (1994) study of 26 African aid recipients found that in most countries where policies had improved, aid levels had fallen, and where policies had worsened, aid had increased. Vasquez (1998) reports that changes in aid tend to be inversely correlated with changes in the Fraser index of economic freedom: where aid is rising (falling), economic freedom tends to fall (rise). Boockmann and Dreher (2003) disaggrega te the Fraser index into its various components, regressing them on aid from the World Bank and IMF, and a set of control variables, using a panel of 85 aid recipients from 1970 to 1997 . In most cases, aid variables for both of the IFIs are insignificant. For the 1990s, however, the number of World Bank programs in a country is associated with higher ratings on several freedom components (including black market premium, private ownership rights, and viability of contracts), but the amount of World Bank credit is negatively associated with these same components. Knack (2001) finds that countries receiving higher levels of aid over the 
1982-95 period tend to experience greater declines in the security of private property, as measured by a rule of law index from the International Country Risk Guide.

These studies either address only limited aspects of market-oriented policies (e.g., Burnside and Dollar, 2000; Knack, 2001), or cover aid only from certain donors (Boockmann and Dreher, 2003), and/or do not correct for potential endogeneity of aid (e.g. Vasquez, 1998). The empirical analysis below attempts to offer a more comprehensive and rigorous test of the net impact of aid on policy liberalization.

\section{Data and Statistical Methodology}

The Fraser economic freedom indexes are now updated annually. We use the 2002 revised dataset, ${ }^{6}$ which includes data on five year intervals from 1975-2000. We use data only from 1980 onward, in part to avoid dropping observations (data are missing for many more countries in 1975), and in part because the emphasis by the IFIs on market-oriented policy reform (including the World Bank's structural adjustment lending) dates to about 1980.

This version of the index has five broad categories or "areas" of market-oriented policies and institutions: Size of Government (Area 1), Legal Structure and Security of Property Rights (Area 2), Access to Sound Money (Area 3), Exchange with Foreigners (Area 4), and Regulation of Credit, Labor and Business (Area 5). Each of these five areas encompasses a variety of individual components which are assigned a score ranging from 0 to 10, with higher values representing greater levels of freedom. Some of the components have several subcomponents. Detailed description of the components and areas which comprise this index are described in Appendix 1. A score for each of the five areas is calculated by the simple average of its various components. The simple average of the five area values then determines the overall economic freedom index (EFI) value. The five areas are equally weighted, but since they contain different numbers of components, a component in an area containing fewer components has greater weight in the final index value. Incomplete data are a concern for several nations. For certain country-year observations, data are missing on some components in a particular area, so the area score is calculated using only partial data. For other observations, data are missing on all components in an area, so no score for the area can be calculated, and the overall index may represent the average of only four instead of five areas. In these cases, the index values are inconsistently measured across nations and/or over time. In effect, missing data on components within an area are imputed as the mean of components with available data in that area, and missing data on areas are imputed as the mean of the remaining areas with available data. If the various components within each area were

\footnotetext{
${ }^{6}$ This dataset is available on-line at: http://freetheworld.com/download.html .
} 
highly correlated, missing data would be unlikely to affect the area value very much. Similarly, if the five areas of the index were all highly correlated, missing data would be unlikely to affect substantially the overall economic freedom value. Correlations among the five areas turn out to be modest, however, making it important to replicate results based on analyses of the full data set with analyses of the restricted data set of countryyears for which data on all areas are available. ${ }^{7}$

We are interested in analyzing aid's impact on market-oriented reforms, reflected in changes in economic freedom over the 1980-2000 period. Table 1 makes clear the importance of considering not only the overall index value, but the separate areas as well. The correlations among changes in the various areas are modest, averaging only .18. Changes in Area 1 are orthogonal to changes in Area 2, and the latter is not significantly related to changes in any of the other areas. Of the ten inter-area correlations, only four are above .25 , and these are the only four that are significantly related to each other at the .05 level. ${ }^{8}$ Correlations of each area with the overall EFI range from .46 (Area 2) to .73 (Area 3).

As shown in Table 2, the average change in the economic freedom index among the 80 developing countries in our study is an improvement of 1.1, on the $0-10$ scale, with 13 nations experiencing a net decline in their economic freedom index. Improvements were largest (averaging about 1.5) in Areas 3 (sound money) and 4 (outward orientation), and smallest (about 0.3) in Area 5 (regulation of credit, labor and business). Average changes over time for Area 2 should be interpreted most cautiously: its underlying components (from the International Country Risk Guide and other sources) are mostly subjectively-assessed, ordinal-level variables without specified criteria for each ratings level; therefore a rating of 4 (for example) may or may not imply the same level of property rights protection in 1985 as in 2000.

For consistency over time, the overall EFI for each country is computed using only those areas and components for which data are available in both 1980 and $2000 .^{9}$ Across countries, however, the change in EFI is measured consistently only if the (unmeasured) change in the components with missing data happens to be equal to the average change in the areas with available data; in fact, some areas tend to show more progress than others. In addition, when focusing on changes in specific areas of

\footnotetext{
${ }^{7}$ Using an earlier version of the Fraser index, Caudill et al. (2000) report that many components are often more highly correlated with other components in different categories than with the components in their own categories.

${ }^{8}$ Correlations among levels of the five areas also average only .18 in 1980, but rising to .33 in 2000 . These correlations are based only on aid recipients in our main sample, but they change little when all countries (including aid donors) in the economic freedom dataset are included.

${ }^{9}$ For example, Uganda has data on all five areas for 2000, but because it has no data on Area 1 for 1980 , we use only the data for Areas 2-5 in computing its EF index change and initial value.
} 
economic freedom, missing data for that area will drop the country from the analysis altogether. To alleviate concerns over the possibility of data and sample inconsistencies, we test for the robustness of our primary findings by also limiting the sample to only those nations without any missing area values. Most of the results hold up under the more limited sample, but some important differences emerge.

Aid is measured by "official development assistance" (ODA) as a percentage of gross national income (GNI), using data for the years 1980-99 from the World Bank's World Development Indicators, which reports data provided by the OECD's Development Assistance Committee, and collected in turn from each donor agency. Aid (ODA) includes grants, and loans with a grant element of more than 25 percent. This definition excludes most IMF lending, as well as the majority (in most years) of World Bank loan volumes, which goes to middle-income borrowers charged near-market rates of interest. Roughly two-thirds of World Bank structural adjustment lending goes to middle-income countries and does not qualify as aid. About one-fourth of World Bank aid to low-income countries is in the form of structural adjustment loans.

Most aid studies (e.g. Burnside and Dollar, 2000) measure aid as a percentage of GNI, but some use aid per capita additionally or instead. We follow the majority of studies in using aid as a percentage of GNI, as it better reflects the leverage donors have with respect to convincing recipient governments and their populations to adopt marketoriented policies. For example, Israel and Jordan each averaged about $\$ 250$ per capita in aid in recent decades, but aid averaged less than $2 \%$ of GNI for Israel and more than $16 \%$ for Jordan. Donors are likely to have far more leverage over policy when their funds account for one-sixth of a recipient's GNI than when they account for one-fiftieth. Aid per capita and aid as a percentage of GNI, each averaged over the 1980-99 period, are correlated in our main sample at only .43 (or .51 using the log of aid per capita), reflecting the divergence between GNI and population (i.e. some aid recipients have much higher per capita incomes than others). We note below how our results vary if aid per capita is used in the analysis instead of the more appropriate aid as a percentage of GNI measure.

Control variables include the initial (1980) economic freedom value, average annual per capita income growth over the 1980-2000 period (based on purchasing power parity income data from the World Development Indicators), linguistic fractionalization, and civil liberties. Initial economic freedom captures any regression-to-the-mean effect, as countries with higher values in 1980 have less room for improvement than those with lower initial values. Rapid growth may disrupt, or reflect the absence of, special interests that tend to block reforms. Controlling for growth may also capture any tendency for the subjectively-assessed components of the index (mainly in area 2, but also in some others) 
to be inferred in part from observed economic performance. ${ }^{10}$ Growth is obviously endogenous to market-oriented policy reform. Using Granger-causality tests, Farr, Lord and Wolfenbarger (1998) find evidence for mutual causality between levels of GDP per capita and levels of the Fraser index, and Dawson (2003) concludes the level of the Fraser index Granger-causes growth, while changes in the index are jointly determined with growth. We therefore show below how results are affected by excluding growth from the regression. Linguistic fractionalization is included, using data from Alesina et al. (2003), as polarized societies may find it more difficult to implement efficient policy reforms, even in the face of economic crisis (Alesina and Drazen, 1991; Easterly and Levine, 1997).

We control for the initial level of civil liberties, and for the change over the period, using data from Freedom House. ${ }^{11}$ Theory and previous evidence do not predict a particular sign on civil liberties. Giving political voice to broader interests may slow reform in some contexts but speed it up in others. Of their 10 African case studies, Devarajan, Dollar and Holmgren (2001: 11) note that the "two strongest reformersRawlings [in Ghana] and Museveni [in Uganda] — came to power through military coups." On the other hand, de Haan and Sturm (2003) find larger improvements in the EF index (1975-90) where the level of political freedom is greater, and Dollar and Svensson (1998) find that democratically elected government increases the likelihood of success for World Bank structural adjustment programs over the period 1980-95. Civil liberties are shown by Burkhart and Lewis-Beck (1994) and Farr, Lord and Wolfenbarger (1998) to be influenced positively by per capita income; for our sample over the 19802000 period, however, growth is correlated with the change in civil liberties at only .01.

Aid, the key independent variable of interest, is potentially endogenous, as donors may direct either more or less aid toward reforming countries. ${ }^{12}$ The World Bank's IDA allocations (accounting for about $10 \%$ of ODA) are determined in part by internal, subjective assessments of the quality of policies and institutions, potentially creating a positive bias in the impact of aid on policy liberalization. The OLS coefficient for aid would capture not only the effect of any positive incentive to reform to qualify for an increased allocation, but also would reflect the impact of policy reform, undertaken for other reasons (e.g. response to crisis, or economic success of other reformers) but still

\footnotetext{
${ }^{10}$ Hanson (2003) criticizes the construction of the economic freedom index, and others similar to it, on the belief that components were chosen for inclusion based on the success of the wealthier nations.

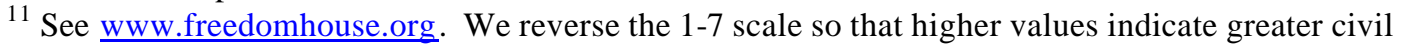
liberties. Initial level and change are correlated at -.58, and both are significant at higher levels when entered together than if either one is included alone. Results reported in the tables are very similar when the Freedom House political freedoms measure is substituted for civil liberties.

12 Bauer (1981: 91) observed that aid is like champagne: "in success you deserve it, in failure you need it" (quoted in Vasquez, 1998: 275).
} 
rewarded with higher aid. There are several reasons to believe the positive bias in the aid-reform relationship implied by these allocation systems to be minor. First, allocations do not always translate one-to-one into aid commitments, and commitments in turn do not always translate one-to-one into disbursements. Aid in the analysis is measured as actual disbursements. Second, most donors do not place the same emphasis on quality of policies and institutions as the IDA allocation system, and even IDA allocations were not well targeted toward recipients with better policies for most of the 1980-2000 period (Easterly, 2002; Dollar and Levin, 2004). Third, the IDA system rewards countries for a high level of policy quality, while our dependent variable is change in the quality of policy. In any event, results reported below are unaffected by subtracting out IDA aid.

There are likely other cases where donors direct aid toward countries with improving policy environments, including some that tend to follow the World Bank's lead. On the other hand, there are likely many other cases where donors focus their aid on countries with poor and/or worsening policy environments, either as an inducement to reform, or as a response to humanitarian crises in poor-performing countries. ${ }^{13}$ On balance, it is a matter of conjecture whether the net effect of all sources of bias would be positive or negative.

To correct for endogeneity concerns, we instrument for aid in two-stage leastsquares regressions using initial (1980) levels of per capita income, adult illiteracy, child mortality, and (log of) population, with data from the World Development Indicators. Appendix 2 reports the first-stage regression. Not only are each of these four instruments significant predictors of aid levels, but collectively they explain a sizeable fraction of variation in aid. As seen by comparing the two columns in the Appendix 2 table, the other second-stage regressors explain only $20 \%$ of the variation in aid in the absence of the four exogenous instruments; with their inclusion $67 \%$ of the variation in aid is explained.

Table 2 provides summary statistics for the 76 countries included in our base sample; Appendix 3 lists these countries, and reports for each one the change and initial level of the EF index, and aid as a percentage of gross national income averaged over the 1980-2000 period.

\section{Results}

Our primary regressions are presented in Table 3 . In column 1 the dependent variable is the overall $\mathrm{EF}$ index, representing the average freedom value of the five areas. The coefficient for initial EF is negative and statistically significant, implying that

\footnotetext{
${ }^{13}$ Including growth in our tests is a partial control for this latter effect.
} 
nations with greater initial "economic freedom" tended to worsen over time, with a nearly three-quarter point decline for each unit increase in the initial EF index value. Growth has a small and statistically insignificant impact on changes in the EF index: even the difference between the highest sample growth rate (.08, for China) to the worst (-.056, for Democratic Republic of Congo) implies an increase of less than a third of a point in EFI.

Policies improve more in countries that are less fractionalized by primary language. The linguistic fractionalization index varies from 0 (El Salvador, Haiti, Korea, and Rwanda) to .9 (Togo, followed closely by Cameroon and Kenya); this difference is associated with a predicted improvement in EFI of nearly half a point more for homogeneous El Salvador relative to heterogeneous Togo. ${ }^{14}$

Both the initial civil liberties value and its change over time are positively and significantly related to policy improvements. The difference in initial civil liberties between the lowest value of 1 (Malawi and Republic of Congo) and highest value of 7 (Barbados and Costa Rica) is associated with a nearly full-point greater increase in EFI. Each 1-point improvement in civil liberties over the period is associated with a nearly quarter-point increase in EFI; in the sample Venezuela has the largest decline (3 points) in civil liberties while Benin, Korea, Malawi South Africa and Uruguay show the largest increases (4 points).

Aid on balance is found to discourage policy reform. Each percentage point increase in aid as a share of national income slows the improvement in EF by .04 . Comparing a country receiving virtually no aid (e.g. Korea) to one receiving $25 \%$ of its GNI in aid (Nicaragua; Guinea-Bissau is highest at 51\%), the former's improvement in EFI is predicted to be a full point higher.

Columns 2-6 respectively replace EFI with the five separate policy areas. Aid is found to discourage policy reform for areas 3 (sound money) and 5 (regulation). The aid coefficient is also large in the case of Area 2 (property rights), consistent with results in Knack (2001), who concludes aid is harmful to security of property rights, using somewhat different time periods and measures of property rights from those used here. However, aid is significant only at the .16 level in the Area 2 regression, which has the smallest sample size among all five areas. The overidentification tests (reported in the bottom row of the table) generally support the validity of the instruments for aid, including for the EF index regression, but not in the regressions for Areas 3 and 4.

\footnotetext{
${ }^{14}$ Alesina et al. (2003) also construct indexes of religious and "ethnic" fractionalization, correlated respectively with linguistic fractionalization in our sample at .28 and .67. Religious fractionalization has a negative but not significant coefficient if added or substituted for the language variable. "Ethnic" fractionalization produces results very similar to linguistic; we use the latter because "ethnicity" is not clearly defined by Alesina et al. (2003). Among the three indexes, linguistic fractionalization best predicts ethnic tensions across countries, using subjective assessments from the International Country Risk Guide (at www.prsgroup.com).
} 
Among the other regressors, the initial EF area value is significant in every case. Growth always has a positive sign, but approaches significance only in the case of Area 2 (property rights). ${ }^{15}$ Fractionalization is most strongly associated with slower reform in Area 4 (openness). Initial civil liberties are most strongly associated with reform in Areas 1 (government size) and 5 (regulation), while the change in civil liberties is most associated with progress in Areas 3-5.

Missing data may complicate comparisons of the effect of aid on the different areas. For example, the Area 3 regression includes 15 more countries than the Area 2 regression. To facilitate comparison, the regressions presented in Table 3 were re-run using the limited sample of 51 nations with scores for every area. Aid's impact in this sample is similar, as shown in Table 4. The negative effect of aid strengthens somewhat for Area 2, and the significance of aid for Area 3 weakens in this smaller sample, despite no change in the coefficient compared to the same regression in Table 3.

Our findings indicate that aid more often than not discourages market-oriented policy and institutional reform. The emphasis on liberal, pro-market reform reflects the general belief that it is necessary for growth to take place. However, as explained in section 2, empirical studies suggest that economic growth is more sensitive to some EF areas than to others (Carlsson and Lundstrom 2002). If aid tends to discourage reform in the policy areas that matter less to growth, our findings on the adverse consequences of aid should be of somewhat less concern. To identify which policy areas appear to have the strongest growth effects, we regressed per capita income growth (1980-2000) on the initial (1980) values of each of the five policy areas, controlling for catch-up opportunities via the inclusion of initial GDP per capita as a sixth regressor. As a partial control for heteroskedasticity, the regression was estimated by weighted least squares, with results presented in Appendix 4. We find that growth is associated with more market-oriented policies in Areas 1, 2, and 3, but with less market-oriented policies in Area 5. The coefficient for Area 4 is also negative, but small and insignificant. Thus, aid appears most likely to harm growth through slowing reform in Areas 2 and 3 (property rights and sound money). Aid may tend to increase growth by slowing reform in Area 5 (regulation), the one policy area for which more "economic freedom" is associated with slower growth in our 51-country sample.

Table 5 reports results on the EF index for several changes in sample or specification. Equations 1 and 2 address the potential objection that the $\$ 15,000$ per capita income threshold for inclusion in our base sample is arbitrary. Equation 1 adds seven high-income aid recipients to our base sample of 76 countries with incomes below

\footnotetext{
${ }^{15}$ Area 2 is the one area measured mostly using subjective measures; these subjective assessments conceivably are influenced by recent growth performance.
} 
$\$ 15,000 .{ }^{16}$ Equation 2 on the other hand deletes 22 middle-income countries from our base sample with incomes above $\$ 4,000$. In both cases, the aid coefficient increases in magnitude (from -.04 to -.06) and significance, relative to the corresponding regression in Table 3 (equation 1).

Equation 3 considers only those 43 countries, from our base sample of 76, with aid exceeding $3 \%$ of GNI on average. Despite the resulting reduction in variation in aid/GNI in this sub-sample, the aid coefficient increases in magnitude (from -.04 to -.07) and significance. We also examined the sensitivity of findings to influential observations (results not shown in tables). Guinea-Bissau easily has the highest aid/GNI value in the sample at $51 \%$, and is also by far the worst policy performer, with a decline of 2.8 points on EFI. Deleting this observation reduces the magnitude of the aid coefficient from -.04 to -.03 , and it is significant only at the .07 level. Results on aid for Area 3 in Table 4 also weaken slightly; other results are unaffected as Guinea-Bissau is not included in the other four areas regressions. On the opposite end of the spectrum, there are many observations with aid levels below $1 \%$ of GNI; of these Argentina shows the largest imp rovement in EFI (2.8). Its deletion however has virtually no impact on aid's coefficient or significance. Results also change little if five micro-states (Belize, Barbados, Bahrain, Fiji and Gabon, all with population under 750,000 in 1980) are deleted from the sample.

Equations 4 and 5 retain the base 76-country sample but alter the specification. Equation 4 omits the endogenous regressor, growth in per capita income, with very little impact on the estimated effects of aid or other variables. Equation 5 adds a dummy variable for Sub-Saharan Africa, where policy reform faces particularly daunting challenges (Johnson, 2004). The EFI averaged only 4.7 in 1980 for the 29 African countries in our base sample, compared to 5.2 for the other 47 , and they also improved less on average between 1980 and 2000: 0.8 for Africa, and 1.2 for countries in other regions. They also average $12 \%$ on aid, compared to less than $4 \%$ for the other countries. The aid variable potentially is capturing the effects of some omitted Africa-specific variable. The Africa dummy variable in equation 5, however, falls far short of attaining significance, and its inclusion has little impact on the aid variable. ${ }^{17}$ In equation 6 , in fact, we show that aid's effect in a regression including only the 29 African countries is similar to its impact in the full sample, conclusively demonstrating that aid is not spuriously capturing an Africa-specific phenomenon of slower policy reform. On the other hand, linguistic fractionalization becomes insignificant when the Africa dummy is added (equation 5), and in the Africa sub-sample (equation 6). These results suggest that

\footnotetext{
${ }^{16}$ These 7 countries, exceeding $\$ 15,000$ in per capita income (purchasing power parity, 1995 dollars) in either 1980 or 2000, include The Bahamas, Cyprus, Israel, Kuwait, Malta, Singapore, and the UAE.

${ }^{17}$ When a complete set of regional dummies was tested, no significant differences among any regions emerged.
} 
the significant effect of fractionalization in the base sample reflects primarily crossregional differences; Africa averages .69 on fractionalization compared to only .29 for the other 47 countries.

We also experimented with other regressors, none of which turned out to be significant, or to alter results on the aid variable. Economic crisis is often credited as a source of policy reform, as it can upset political equilibria previously blocking the adoption or implementation of reforms (e.g. Devarajan, Dollar and Holmgren, 2001: ch.1; Bambaci, Saront and Tommasi, 2002). Crisis can be measured only very crudely when examining only the net outcome of all reform occurring over a 20 -year period, so it is unsurprising that our measures had little explanatory power. We tested three proxies for crisis: (1) changes in the terms of trade between 1980 and 2000, (2) terms of trade volatility during the period, and (3) debt default, measured as the number of Paris Club debt re-schedulings. ${ }^{18}$ Of these, only a dummy variable for having re-scheduled debt at least once is even marginally significant, with a coefficient of +.37 . Interpretation of this finding is not straightforward: debt re-scheduling is not only an indicator of crisis, but also of an aid relationship, as countries benefiting from re-scheduling agreements are required to have a current program with the IMF committing them to implement reforms.

We also tested several political economy variables from Beck et al. (2000), following work by Myerson (1999) and Persson and Tabellini $(2004,2002)$ showing that electoral rules and other political institutions can affect government spending and corruption levels. A plausible hypothesis, for example, is that reform would be hampered by presence of a chief executive from a left-wing party, or presence of a coalition government. However, the share of years from 1980-2000 in which a country had coalition government, or an executive from a left-wing party, proved to be unrelated to changes in EFI. ${ }^{19}$ Similarly, the average level of party fractionalization in parliament overall, and in the government coalition in parliament, were insignificant. Parliamentary district magnitude, proportional representation, and presidential systems also had no relation to policy reform in our sample. Nor did the addition of any of these variables affect the strength of the estimated relationship between aid and policy reform. Moreover, results described in this paragraph are unaffected by deleting non-democracies from the sample, or by omitting the civil liberties measures from the equation.

\footnotetext{
${ }^{18}$ See www.clubdeparis.org. The number varied in our base sample from 0 (for 27 countries) to 14 (Senegal), with a mean of 3 .

${ }^{19}$ When left-wing governments advocate market-liberalizing reforms, on efficiency-enhancing grounds, they are likely to have greater credibility with the public than right-wing governments, which many voters might suspect to advocate reform purely for ideological reasons whatever the stated objective (Cukierman and Tommasi, 1998). Examples include early 1980s Ghana under Jerry Rawlings (Devarajan, Dollar, and Holmgren, 2001: ch. 2), and early 1990s Argentina under the Peronist Carlos Menem (Bambaci, Saront and Tommasi, 2002: 81).
} 
Equation 7 of Table 5 substitutes (the log of) aid per capita for aid as a percentage of GNI. The coefficient remains negative, but is not significant. This finding may suggest that high aid levels in middle-income countries - where aid per capita is high but aid/GNI is low - are less likely to inhibit reform as in poorer countries. When we retain aid/GNI, but drop the poorest countries from the sample (10 have per capita incomes under $\$ 1,000$ in 1980), we also find the aid coefficient negative but insignificant.

Our final investigations, reported in Table 6, compare aid's impact before and after the end of the Cold War. Aid allocation decisions by the U.S. and other donors during the Cold War were often dominated by strategic considerations, potentially at the expense of market-liberalizing policy reform, as corrupt regimes such as Mobutu's in Congo-Zaire were propped up by aid. The 1990s also witnessed an increased donor emphasis on the quality of governance, including protection of property rights, reflected mainly in Area 2 of the Fraser index. Moreover, the IFIs may have learned from some of their early mistakes with structural adjustment lending and conditionality; ratings by the World Bank's Operations Evaluation Department show large increases from the 1980s to the 1990s in the percentage of adjustment loans with "satisfactory" or better outcomes (Killick, 2004; World Bank, 2004). Whether for these or other reasons, the 1990s saw much more reform than the 1980s: the mean change in EFI for our 76-country base sample is only .17 for the 1980 s, but .85 for the $1990 \mathrm{~s}^{20}$ Moreover, although countries receiving high aid levels as a share of GNI in the 1980s also tended to be recipients of large aid volumes in the 1990s (the correlation is .82), this is not true for reform: the change in EFI across decades is actually negatively correlated (-.20, significant at .10). A final reason for breaking the period into decades is to permit the inclusion of many exCommunist countries that embarked on the transition to market economies and began receiving aid from the West in the 1990s.

Table 6 presents regression results for the change in EFI separately by decade, adjusting all variables accordingly. As in the 1980-2000 tests, the aid coefficient is negative and highly significant for the $1980-90$ period. For the same set of countries, however, aid is not significantly related to the change in EFI in the 1990s. Other notable differences across decades are that civil liberties and growth mattered more in the 1990s than in the 1980s.

Equation 3 also considers the 1990-2000 period, but adds 13 ex-Soviet bloc countries which abandoned socialism and became recipients of substantial aid in that

\footnotetext{
${ }^{20}$ All five areas showed large improvements on average in the base sample in the 1990s, particularly in areas 3 (sound money) and 4 (openness). In the 1980s average ratings improved only for areas 1 (government size) and 4.
} 
decade. $^{21}$ The average increase in EFI among these 13 in the 1990s was 1.15, compared to 0.85 for the other 76 countries. The addition of these 13 countries in equation 3 further weakens the aid coefficient, and further strengthens the coefficient on income growth.

Equation 4 adds an EU accession dummy, which has a positive and significant coefficient of .66, indicating that the carrot of membership generated more extensive policy reform for the seven new EU members (admitted in May 2004) in our sample, other things equal. $^{22}$ There is potentially reciprocal causation, however, as reforms undertaken for other reasons (e.g. in response to crisis) could enhance the chances for membership.

\section{Discussion}

Our results show that over the 1980-2000 period, countries receiving higher levels of aid were less likely to adopt market-oriented reforms than those receiving low aid levels. Although this finding may be welcomed by aid skeptics who believe a "world without development aid" would experience more "real reform" toward market-oriented policies (Vasquez, 1998: 276), several important qualifications to our work suggest a more favorable view of at least some donor programs.

First, our decade analyses are consistent with other evidence (e.g. Koeberle, 2003: 253 ) that donors' attempts to influence policy have become more effective (or less counterproductive) over time. Donors now more readily acknowledge the primacy of domestic political economy factors in determining the direction and pace of reform (World Bank, 2004), and recognize that aid is likely to facilitate reform only where a significant commitment exists within the government. Technical support by donors is important, but only where there is a well-articulated demand for it. Conditionality is often welcomed by technocrats in the early stages of reform, to obtain clear decisions from the political leadership and to signal publicly the seriousness of reform (Devarajan, Dollar, and Holmgren, 2001: 30). Once reform measures are well established, however, donors should abandon conditionality so that local ownership and management is clear.

Second, the impact of donors should not be equated with the impact of aid volumes. Policy advice can be effective in countries with small aid programs, measured as a share of GNI. Examples include China and the Dominican Republic (World Bank, 2004: 18, 27-28; Mallaby, 2004: 410). Key economic officials in reforming countries

\footnotetext{
${ }^{21}$ These countries are Albania, Bulgaria, Croatia, Czech Republic, Estonia, Hungary, Latvia, Lithuania, Poland, Romania, Slovak Republic, Russia and Ukraine.

22 These seven include Czech Republic, Estonia, Hungary, Latvia, Lithuania, Poland and Slovak Republic. Cyprus, Malta and Slovenia are also new members but are not included in our sample. Alternative dummies that include Bulgaria and Romania (on track for membership in 2007), and Croatia and Turkey (negotiating for membership) have positive but insignificant coefficients.
} 
often benefited from donor-sponsored overseas training programs which account for only a tiny fraction of aid volumes (World Bank, 1998: 55).

Third, donors' impact may go beyond country-specific aid and advice. The IFIs and other donors disseminate ideas globally, potentially contributing to the spread of market-oriented reforms through provision of intellectual public goods. For example, most of the data underlying the Fraser Institute's index, and which are heavily relied on in numerous academic studies on the growth effects of economic policy, are generated by the IMF. The World Bank and IMF are the largest producers and distributors of advocacy pieces for market-oriented policy and institutional reforms, in their numerous reports and working papers. In recent decades, according to Mallaby (2004: 71), "...the Bank's annual World Development Report often established the accepted wisdom among development thinkers. Commentators outside the Bank spent much of their time reacting to World Bank ideas and citing World Bank data." The World Bank maintains web sites designed for use by staff, government officials and NGO reform advocates which disseminate "best practice" knowledge on reform in numerous policy areas such as legal and judicial reform, anti-corruption, and tax policy and administration. A Bankcommissioned survey of 2,600 "opinion leaders" in government, academia, civil society, trade unions and the private sector, conducted in 2002-2003 in 35 developing and 13 industrial countries, supports the effectiveness of these activities. Most respondents reported that World Bank publications substantially influenced their thinking on development issues, that the Bank was effective in contributing to the economic debate in their countries, and that it was "an excellent source of research, analysis and knowledge" including data on issues relevant to their countries. Responses were even more favorable in less-developed than in industrialized countries (Princeton Survey Research Associates, 2003).

Fourth, donors often have other objectives instead of or in addition to policy reform to stimulate private sector development. Education and health policy, for example, are not reflected in the Fraser index. Non-policy objectives, including humanitarian, gender equity, environmental, and bilateral donors' foreign policy goals, may also justify aid programs. The effectiveness of aid in meeting many of these goals has not been sufficiently analyzed, but donors may view their aid programs as successful on these terms even if they are counterproductive in generating market-friendly policy reforms.

This study has analyzed the impact of all ODA on market-oriented policy reform. Some forms of aid, from some donors, may be more effective (or at least less harmful) than others. Further research could disaggregate aid by type (technical assistance, project lending and budget support), or by donor agency (World Bank, IMF, UN agencies, various bilaterals), or by sector (e.g. aid for banking and financial services, or for 
strengthening civil society and public sector accountability and capacity), to examine potential differences in their impact on market-liberalizing reform. Further research could also examine the impact of financial flows other than ODA, including nonconcessional lending by aid agencies. Finally, the impact of other factors, including economic crises, changes in government and other political economy variables, could be investigated more thoroughly, by examining 5-year periods instead of the 10 and 20-year periods analyzed in this study.

\section{References}

Alesina, Alberto and David Dollar (2000). "Who Gives Foreign Aid to Whom and Why"? Journal of Economic Growth 5: 33-63.

Alesina, Alberto; Arnaud Devleeschauwer, William Easterly, Sergio Kurlat and Romain Wacziarg (2003). "Fractionalization." Journal of Economic Growth 8: 155-94.

Alesina, Alberto and Allen Drazen (1991). "Why are Stabilizations Delayed?" American Economic Review 81(5): 1170-88.

Ayal, Eliezer B. and Georgios Karras (1998). "Compone nts of Economic Freedom and Growth: An Empirical Study.” The Journal of Developing Areas 32: 327-338.

Bambaci, Juliana; Tamara Saront and Mariano Tomassi (2002). "The Political Economy of Economic Reforms in Argentina." Journal of Policy Reform 5(2): 75-88.

Barro, Robert (1997). Determinants of Economic Growth: A Cross-Country Empirical Study. Cambridge: MIT Press.

Barro, Robert (1991). "Economic Growth in a Cross Section of Countries." Quarterly Journal of Economics, 106(2): 407-43.

Bauer, Peter T. (1984). Reality and Rhetoric: Studies in the Economics of Development. Cambridge: Harvard University Press.

Bauer, Peter T. (1981). Equality, the Third World, and Economic Delusion. Cambridge: Harvard University Press.

Beck, Thorsten; George Clarke, Alberto Groff, Philip Keefer and Patrick Walsh (2000). "New Tools and New Tests in Comparative Political Economy." World Bank Policy Research Working Paper No. 2283.

Berggren, Niclas (2003). "The Benefits of Economic Freedom: A Survey." The Independent Review 8: 193-211.

Boockmann, Bernhard and Axel Dreher (2003). "The Contribution of the IMF and the World Bank to Economic Freedom." European Journal of Political Economy 19: 633-49. 
Brautigam, Deborah (2000). Aid Dependence and Governance. Stockholm: Almqvist \& Wiksell International.

Burkhart, Ross and Michael Lewis-Beck (1994) "Comparative Democracy: The Economic Development Thesis." American Political Science Review 88(4): 90310.

Burnside, Craig and David Dollar (2000). "Aid, Policies, and Growth." American Economic Review 90(4): 847-68.

Carlsson, Fredrik and Susanna Lundström (2002). "Economic Freedom and Growth: Decomposing the Effects." Public Choice 112: 335-34.

Caudill, Stephen B., Fernando C. Zanella, and Franklin G. Mixon, Jr. (2000). "Is Economic Freedom One Dimension? A Factor Analysis of Some Common Measures of Economic Freedom." Journal of Economic Development 25(1): 1740 .

Claessens, Stijn and Luc Laeven (2003). "Financial Development, Property Rights, and Growth." Journal of Finance 58(6): 2401-36.

Collier, Paul (1997). "The Failure of Conditionality." In C. Gwin and J. M. Nelson, eds., Perspectives on Aid and Development. Washington, DC: Overseas Development Council.

Cukierman, Alex and Mariano Tommasi (1998). "When Does it Take A Nixon to Go to China?" American Economic Review 88(1): 180-97.

Dawson, John (2003). "Causality in the Freedom-Growth Relationship." European Journal of Political Economy 19: 479-95.

De Haan, Jakob and Jan-Egbert Sturm (2003). "Does More Democracy Lead to Greater Econo mic Freedom? New Evidence for Developing Countries." European Journal of Political Economy 19(3): 547-63.

Devarajan, Shanta; David Dollar and Torgny Holmgren (2001). Aid and Reform in Africa. Washington, D.C.: The World Bank.

Dollar, David and Victoria Levin (2004). "The Increasing Selectivity of Foreign Aid, 1984-2002.” World Bank Policy Research Working Paper 3299.

Dollar, David and Jakob Svensson (2000). "What Explains the Success or Failure of Structural Adjustment Programs?” Economic Journal 110(466): 894-917.

Easterly, William, and Ross Levine (1997). “Africa's Growth Tragedy: Policies and Ethnic Divisions." Quarterly Journal of Economics 112(4): 1203-50

Easterly, William, Ross Levine and David Roodman (2004). "Aid, Policies, and Growth: Comment." American Economic Review 94(3): 774-80.

Easterly, William, and Sergio Rebelo (1993). "Fiscal Policy and Economic Growth: An 
Empirical Investigation." Journal of Monetary Economics 32: 417-58.

Easterly, William (2005). "What Did Structural Adjustment Adjust? The Association of Policies and Growth With Repeated IMF and World Bank Adjustment Loans." Journal of Development Economics 76: 1-22.

Easterly, William (2002). "The Cartel of Good Intentions: The Problem of Bureaucracy in Foreign Aid." Journal of Policy Reform 5(4): 223-50.

Farr, W. Ken; Richard A. Lord and J. Larry Wolfenbarger (1998). "Economic Freedom, Political Freedom, and Economic Well-Being: A Causality Analysis." Cato Journal 18(2): 247-62.

Feyzioglu, Tarhan, Vinaya Swaroop and Min Zhu (1998). "A Panel Data Analysis of the Fungibility of Foreign Aid." World Bank Economic Review 12(1): 29-58.

Fischer, Stanley (1993). "The Role of Macroeconomic Factors in Growth." Journal of Monetary Economics 32: 485-512.

Frankel, Jeffrey A. and David Romer (2000). "Does Trade Cause Growth?" American Economic Review 89(3): 379-99.

Friedman, Milton (1958). "Foreign Economic Aid: Means and Objectives." Yale Review 47(4): 500-16.

Goldsmith, Arthur A. (1997). "Economic Rights and Government in Developing Countries: Cross-National Evidence on Growth and Development." Studies in Comparative International Development 32: 29-44.

Grossman, Herschel I. (1992). "Foreign Aid and Insurrection." Defense Economics 3: $275-88$.

Gwartney, James and Robert Lawson (2004). Economic Freedom of the World: 2004 Annual Report. Vancouver, B.C.: The Fraser Institute.

Hansen, Henrik and Finn Tarp (2000). "Aid Effectiveness Disputed." Journal of International Development 12(3): 375-98.

Hanson, John R. (2003). "Proxies in the New Political Economy: Caveat Emptor." Economic Inquiry 41(4): 639-46.

Heckelman, Jac C. and Michael D. Stroup (2000). "Which Economic Freedoms Contribute to Growth?" Kyklos 54: 527-44.

Holcombe, Randall G. (2001). "Public Choice and Economic Growth," in William F. Shughart II and Laura Razzolini (eds). The Elgar Companion to Public Choice. Cheltenham, UK: Edward Elgar Publishing.

Hsieh, Chang-Tai (2000). "Bargaining Over Reform.” European Economic Review 44: 1659-76. 
Ivanova, Anna; Wolfgang Mayer, Alex Mourmouras and George Anayiotos (2003). "What Determines the Implementation of IMF-Supported Programs?" IMF Working Paper WP/03/8. Washington D.C.: International Monetary Fund.

Johnson, Omotunde E. G. (2004). "How Will Good Economic Policy Environments Emerge in Africa?" Journal of Policy Reform 7(3): 151-64.

Kapur, Devesh and Richard Webb (2000). "Governance-Related Conditionalities of the IFIs." Prepared for the XII Technical Group meeting of the Intergovernmental Group of 24 for International Monetary Affairs, Lima, Peru, March 1-3.

Killick, Tony (2004). "Politics, Evidence and the New Aid Agenda." Development Policy Review 22(1): 5-29.

Killick, Tony (1995). "Conditionality and the Adjustment-Development Connection." Pakistan Journal of Applied Economics 11(1\&2): 17-36.

Knack, Stephen (2001). "Aid Dependence and the Quality of Governance: Cross-Country Empirical Tests." Southern Economic Journal 68(2): 310-29.

Knack, Stephen and Philip Keefer (1995). "Institutions and Economic Performance: Cross-Country Tests Using Alternative Institutional Measures." Economics and Politics 7(3): 207-27.

Koeberle, Stefan G. (2003). "Should Policy-Based Lending Still Involve Conditionality?" World Bank Research Observer 18(2): 249-73.

Loayza, Norman; Ana Maria Oviedo and Luis Serven (2005). "Regulation and Macroeconomic Performance." World Bank Policy Research Working Paper 3469.

Loayza, Norman and Raimundo Soto (2004). "On the Measurement of Market-Oriented Reforms."World Bank Policy Research Working Paper 3371.

Mallaby, Sebastian (2004). The World's Banker: A Story of Failed States, financial Crises, and the Wealth and Poverty of Nations. New York: Penguin Press.

Myerson, Roger (1999). “Theoretical Comparisons of Electoral Systems.” European Economic Review 43: 671-97.

Persson, Torssten and Guido Tabellini (2004). "Constitutions and Economic Policy." Journal of Economic Perspectives 18(1): 75-98.

Persson, Torssten and Guido Tabellini (2002). "Do Constitutions Cause Large Governments? Quasi- Experimental Evidence." European Economic Review 46: 908-18.

Princeton Survey Research Associates (2003). "The Global Poll: Multinational Survey of Opinion Leaders 2002." Washington, DC.

Rodrik, Dani (1996). “Understanding Economic Policy Reform.” Journal of Economic 
Literature 34: 9-41.

Vasquez, Ian (1998). “Official Assistance, Economic Freedom, and Policy Change: Is Foreign Aid Like Champagne?” Cato Journal 18(2): 275-86.

Williamson, John (2000). 'What Should the World Bank Think About the Washington Consensus?" World Bank Research Observer 15(2): 251-64.

World Bank (2004). 2003 Annual Review of Development Effectiveness: The Effectiveness of Bank Support for Policy Reform. Operations Evaluation Department. Washington, D.C.: The World Bank.

World Bank (1998). Assessing Aid: What Works, What Doesn't, and Why. New York: Oxford University Press.

World Bank (1994). Adjustment in Africa: Reform, Results and the Road Ahead. World Bank Policy Research Report. Washington DC: The World Bank. 


\section{Table 1}

Pairwise Correlation Matrix: changes in economic freedom, 1980-2000

$\begin{array}{lrrrrr} & \text { EF Index } & \text { AREA1 } & \text { AREA2 } & \text { AREA3 } & \text { AREA4 } \\ \text { AREA1 } & 0.54^{*} & & & & \\ & (73) & & & & \\ \text { AREA2 } & 0.46^{*} & 0.00 & & & \\ & (60) & (59) & & & \\ \text { AREA3 } & 0.74^{*} & 0.08 & 0.14 & & \\ & (75) & (72) & (60) & & \\ \text { AREA4 } & 0.56^{*} & 0.25^{*} & 0.09 & 0.16 & \\ & (71) & (70) & (59) & (71) & \\ \text { AREA5 } & 0.60^{*} & 0.31^{*} & 0.05 & 0.38^{*} & 0.30^{*} \\ & (66) & (64) & (52) & (66) & (64)\end{array}$

A * indicates significance at .05 level. Sample size in parentheses.

Table 2

Summary statistics for main sample $(\mathrm{N}=76)$

Economic Freedom Index, change

Economic Freedom Index, initial

Aid/GNI (percent)

Growth

Linguistic fractionalization

Civil liberties, initial

Civil liberties, change

GDP, initial

Child mortality rate, initial

Illiteracy rate, initial

Population, initial (millions)

$\begin{array}{rrrr}\text { Mean } & \text { Std. Dev. } & \text { Minimum } & \text { Maximum } \\ 1.03 & 1.04 & -2.83 & 3.45 \\ 4.97 & 0.96 & 1.70 & 7.31 \\ 6.88 & 8.32 & 0.03 & 51.16 \\ 0.01 & 0.02 & -0.056 & 0.081 \\ 0.44 & 0.33 & 0.00 & 0.92 \\ 3.49 & 1.48 & 1 & 7 \\ 0.76 & 1.51 & -3 & 4 \\ 3375 & 2834 & 462 & 14830 \\ 126.95 & 74.29 & 18 & 336 \\ 42.3 & 24.8 & 1.17 & 92.05 \\ 39.08 & 136.52 & 0.15 & 981.24\end{array}$


Table 3

Aid and Economic Freedom, 1980-2000

2SLS regressions (full sample)

\begin{tabular}{|c|c|c|c|c|c|c|}
\hline Equation & 1 & 2 & 3 & 4 & 5 & 6 \\
\hline $\mathrm{EF}$ variable & Index & Area 1 & Area 2 & Area 3 & Area 4 & Area 5 \\
\hline Constant & $\begin{array}{c}4.41 \\
(8.44)\end{array}$ & $\begin{array}{c}3.63 \\
(5.24)\end{array}$ & $\begin{array}{c}4.41 \\
(5.65)\end{array}$ & $\begin{array}{c}6.35 \\
(5.93)\end{array}$ & $\begin{array}{c}4.79 \\
(8.00)\end{array}$ & $\begin{array}{c}2.91 \\
(6.31)\end{array}$ \\
\hline Initial EF value & $\begin{array}{c}-0.72 \\
(-8.39)\end{array}$ & $\begin{array}{l}-0.63 \\
(-8.34)\end{array}$ & $\begin{array}{l}-0.92 \\
(-8.84)\end{array}$ & $\begin{array}{l}-0.85 \\
(-7.98)\end{array}$ & $\begin{array}{l}-0.73 \\
(-9.15)\end{array}$ & $\begin{array}{l}-0.61 \\
(-7.44)\end{array}$ \\
\hline $\begin{array}{l}\text { Avg. annual growth } \\
\text { in per capita income }\end{array}$ & $\begin{array}{c}2.40 \\
(0.58)\end{array}$ & $\begin{array}{c}-0.04 \\
(-0.01)\end{array}$ & $\begin{array}{r}14.47 \\
(1.72)\end{array}$ & $\begin{array}{l}4.36 \\
(0.44)\end{array}$ & $\begin{array}{c}2.57 \\
(0.50)\end{array}$ & $\begin{array}{c}1.18 \\
(0.31)\end{array}$ \\
\hline $\begin{array}{l}\text { Linguistic } \\
\text { fractionalization }\end{array}$ & $\begin{array}{l}-0.50 \\
(-1.89)\end{array}$ & $\begin{array}{l}-0.51 \\
(-1.26)\end{array}$ & $\begin{array}{c}-0.22 \\
(-0.48)\end{array}$ & $\begin{array}{c}-0.52 \\
(-0.83)\end{array}$ & $\begin{array}{l}-0.58 \\
(-1.79)\end{array}$ & $\begin{array}{l}-0.11 \\
(-0.44)\end{array}$ \\
\hline Initial civil liberties & $\begin{array}{c}0.15 \\
(1.96)\end{array}$ & $\begin{array}{l}0.25 \\
(2.27)\end{array}$ & $\begin{array}{c}0.03 \\
(0.18)\end{array}$ & $\begin{array}{c}0.07 \\
(0.42)\end{array}$ & $\begin{array}{c}0.14 \\
(1.61)\end{array}$ & $\begin{array}{c}0.22 \\
(3.09)\end{array}$ \\
\hline $\begin{array}{l}\text { Change in civil } \\
\text { liberties }\end{array}$ & $\begin{array}{c}0.23 \\
(3.46)\end{array}$ & $\begin{array}{c}0.14 \\
(1.43)\end{array}$ & $\begin{array}{c}0.19 \\
(1.63)\end{array}$ & $\begin{array}{c}0.40 \\
(2.55)\end{array}$ & $\begin{array}{c}0.17 \\
(2.13)\end{array}$ & $\begin{array}{c}0.19 \\
(3.19)\end{array}$ \\
\hline Aid & $\begin{array}{c}-0.04 \\
(-3.01)\end{array}$ & $\begin{array}{c}-0.01 \\
(-0.42) \\
\end{array}$ & $\begin{array}{c}-0.04 \\
(-1.41) \\
\end{array}$ & $\begin{array}{c}-0.08 \\
(-2.29)\end{array}$ & $\begin{array}{c}-0.01 \\
(-0.62)\end{array}$ & $\begin{array}{c}-0.05 \\
(-2.77)\end{array}$ \\
\hline $\mathrm{N}$ & 76 & 73 & 60 & 75 & 71 & 66 \\
\hline Mean, dep. var. & 1.03 & 1.20 & 0.61 & 1.51 & 1.56 & 0.25 \\
\hline Std. error of est. & 0.69 & 1.00 & 1.10 & 1.60 & 0.81 & 0.59 \\
\hline $\begin{array}{l}\mathrm{P} \text { value from overid } \\
\text { test }\end{array}$ & .56 & .17 & .74 & .06 & .01 & .66 \\
\hline
\end{tabular}

T-statistics below coefficient estimates. Exogenous instruments for aid include initial year values of per capita income, child mortality, illiteracy and population. 
Table 4

Aid and Economic Freedom, 1980-2000

2SLS regressions (sample with data on all EF areas)

\begin{tabular}{|l|c|c|c|c|c|c|}
\hline Equation & 1 & 2 & 3 & 4 & 5 & 6 \\
\hline EF variable & Index & Area 1 & Area 2 & Area 3 & Area 4 & Area 5 \\
\hline Constant & $\begin{array}{c}4.21 \\
(6.67)\end{array}$ & $\begin{array}{c}2.93 \\
(3.57)\end{array}$ & $\begin{array}{c}4.84 \\
(5.42)\end{array}$ & $\begin{array}{c}5.86 \\
(4.22)\end{array}$ & $\begin{array}{c}3.87 \\
(5.67)\end{array}$ & $\begin{array}{c}2.77 \\
(4.53)\end{array}$ \\
\hline Initial EF value & -0.78 & -0.70 & -0.90 & -0.81 & -0.69 & -0.67 \\
$(-7.41)$ & $(-7.58)$ & $(-7.69)$ & $(-6.63)$ & $(-8.81)$ & $(-6.26)$ \\
\hline $\begin{array}{l}\text { Avg. annual growth } \\
\text { in per capita income }\end{array}$ & $\begin{array}{c}4.27 \\
(0.86)\end{array}$ & $\begin{array}{c}11.10 \\
(1.41)\end{array}$ & $\begin{array}{c}11.39 \\
(1.21)\end{array}$ & $\begin{array}{c}5.13 \\
(0.36)\end{array}$ & $\begin{array}{c}-1.43 \\
(-0.24)\end{array}$ & $\begin{array}{c}-1.96 \\
(-0.39)\end{array}$ \\
\hline $\begin{array}{l}\text { Linguistic } \\
\text { fractionalization }\end{array}$ & $\begin{array}{c}-0.33 \\
(-1.11)\end{array}$ & $\begin{array}{c}-0.26 \\
(-0.55)\end{array}$ & $\begin{array}{c}-0.20 \\
(-0.36)\end{array}$ & $\begin{array}{c}-0.76 \\
(-0.93)\end{array}$ & $\begin{array}{c}-0.33 \\
(-0.92)\end{array}$ & $\begin{array}{c}-0.08 \\
(-0.25)\end{array}$ \\
\hline Initial civil liberties & $\begin{array}{c}0.23 \\
(2.60)\end{array}$ & $\begin{array}{c}0.49 \\
(3.39)\end{array}$ & $\begin{array}{c}-0.07 \\
(-0.39)\end{array}$ & $\begin{array}{c}0.10 \\
(0.40)\end{array}$ & $\begin{array}{c}0.31 \\
(2.89)\end{array}$ & $\begin{array}{c}0.33 \\
(3.30)\end{array}$ \\
\hline Change in civil & $\begin{array}{c}0.28 \\
\text { liberties }\end{array}$ & $\begin{array}{c}0.22 \\
(1.05)\end{array}$ & $\begin{array}{c}0.17 \\
(1.27)\end{array}$ & $\begin{array}{c}0.47 \\
(2.46)\end{array}$ & $\begin{array}{c}0.22 \\
(2.61)\end{array}$ & $\begin{array}{c}0.29 \\
(3.80)\end{array}$ \\
\hline Aid & -0.04 & 0.01 & -0.07 & -0.08 & 0.001 & -0.05 \\
$(-1.99)$ & $(0.20)$ & $(-1.78)$ & $(-1.45)$ & $(0.04)$ & $(-2.35)$ \\
\hline N & 51 & 51 & 51 & 51 & 51 & 51 \\
\hline Mean, dep. var. & 1.04 & 1.29 & 0.55 & 1.49 & 1.53 & 0.31 \\
\hline Std. error of est. & 0.59 & 0.96 & 1.10 & 1.70 & 0.72 & 0.62 \\
\hline P value from overid & .49 & .64 & .46 & .20 & .01 & .64 \\
\hline
\end{tabular}

T-statistics below coefficient estimates. Exogenous instruments for aid include initial year values of per capita income, child mortality, illiteracy and population. 
Table 5

Aid and Economic Freedom index, 1980-2000

2SLS regressions (full sample)

\begin{tabular}{|c|c|c|c|c|c|c|c|}
\hline Equation & 1 & 2 & 3 & 4 & 5 & 6 & 7 \\
\hline Variation & $\begin{array}{l}7 \text { high- } \\
\text { income } \\
\text { added }\end{array}$ & $\begin{array}{l}\text { GDP80 } \\
>4000 \\
\text { deleted }\end{array}$ & $\begin{array}{c}\text { aid/GNI } \\
<3 \% \\
\text { deleted }\end{array}$ & $\begin{array}{l}\text { Growth } \\
\text { omitted }\end{array}$ & $\begin{array}{l}\text { Africa } \\
\text { dummy }\end{array}$ & $\begin{array}{l}\text { Africa } \\
\text { only }\end{array}$ & $\begin{array}{c}\text { Log aid } \\
\text { per } \\
\text { capita }\end{array}$ \\
\hline Constant & $\begin{array}{c}4.84 \\
(8.80)\end{array}$ & $\begin{array}{c}5.29 \\
(8.37)\end{array}$ & $\begin{array}{c}5.02 \\
(6.57)\end{array}$ & $\begin{array}{c}4.41 \\
(8.39)\end{array}$ & $\begin{array}{c}4.46 \\
(8.47)\end{array}$ & $\begin{array}{c}3.40 \\
(3.09)\end{array}$ & $\begin{array}{c}4.15 \\
(7.11)\end{array}$ \\
\hline Initial EF value & $\begin{array}{l}-0.70 \\
(-8.14)\end{array}$ & $\begin{array}{c}-0.89 \\
(-7.81)\end{array}$ & $\begin{array}{c}-0.72 \\
(-5.58)\end{array}$ & $\begin{array}{c}-0.71 \\
(-8.34)\end{array}$ & $\begin{array}{c}-0.73 \\
(-8.37)\end{array}$ & $\begin{array}{c}-0.56 \\
(-3.83)\end{array}$ & $\begin{array}{c}-0.70 \\
(-7.49)\end{array}$ \\
\hline $\begin{array}{l}\text { Avg. growth in } \\
\text { per capita income }\end{array}$ & $\begin{array}{c}-0.37 \\
(-0.09)\end{array}$ & $\begin{array}{c}-1.01 \\
(-0.22)\end{array}$ & $\begin{array}{r}2.77 \\
(0.39)\end{array}$ & & $\begin{array}{c}1.90 \\
(0.46)\end{array}$ & $\begin{array}{l}12.04 \\
(1.42)\end{array}$ & $\begin{array}{c}4.52 \\
(0.99)\end{array}$ \\
\hline $\begin{array}{l}\text { Linguistic } \\
\text { fractionalization }\end{array}$ & $\begin{array}{c}-0.45 \\
(-1.56)\end{array}$ & $\begin{array}{c}-0.56 \\
(-1.96)\end{array}$ & $\begin{array}{l}-0.82 \\
(-2.39)\end{array}$ & $\begin{array}{c}-0.51 \\
(-1.93)\end{array}$ & $\begin{array}{c}-0.39 \\
(-1.22)\end{array}$ & $\begin{array}{c}0.19 \\
(0.38)\end{array}$ & $\begin{array}{c}-0.58 \\
(-2.02)\end{array}$ \\
\hline $\begin{array}{l}\text { Initial civil } \\
\text { liberties }\end{array}$ & $\begin{array}{c}0.06 \\
(0.81)\end{array}$ & $\begin{array}{c}0.21 \\
(2.34)\end{array}$ & $\begin{array}{c}0.15 \\
(1.31)\end{array}$ & $\begin{array}{c}0.15 \\
(2.00)\end{array}$ & $\begin{array}{c}0.14 \\
(1.95)\end{array}$ & $\begin{array}{c}0.19 \\
(0.96)\end{array}$ & $\begin{array}{c}0.21 \\
(2.67)\end{array}$ \\
\hline $\begin{array}{l}\text { Change in civil } \\
\text { liberties }\end{array}$ & $\begin{array}{l}0.16 \\
(2.29)\end{array}$ & $\begin{array}{c}0.33 \\
(3.73)\end{array}$ & $\begin{array}{c}0.28 \\
(2.61)\end{array}$ & $\begin{array}{c}0.23 \\
(3.55)\end{array}$ & $\begin{array}{c}0.23 \\
(3.52)\end{array}$ & $\begin{array}{c}0.07 \\
(0.56)\end{array}$ & $\begin{array}{c}0.22 \\
(3.07)\end{array}$ \\
\hline Aid & $\begin{array}{c}-0.06 \\
(-4.06)\end{array}$ & $\begin{array}{c}-0.06 \\
(-3.76)\end{array}$ & $\begin{array}{c}-0.07 \\
(-3.17)\end{array}$ & $\begin{array}{c}-0.04 \\
(-3.36)\end{array}$ & $\begin{array}{c}-0.04 \\
(-2.43)\end{array}$ & $\begin{array}{c}-0.05 \\
(-2.73)\end{array}$ & $\begin{array}{c}-0.09 \\
(-1.06)\end{array}$ \\
\hline $\begin{array}{l}\text { Sub-Saharan } \\
\text { Africa dummy }\end{array}$ & & & & & $\begin{array}{c}-0.16 \\
(-0.63)\end{array}$ & & \\
\hline $\mathrm{N}$ & 83 & 54 & 43 & 76 & 76 & 29 & 76 \\
\hline Mean, dep. var. & 1.07 & 0.98 & 1.03 & 1.03 & 1.03 & 0.82 & 1.03 \\
\hline Std. error of est. & 0.76 & 0.67 & 0.72 & 0.69 & 0.69 & 0.65 & 0.75 \\
\hline $\begin{array}{l}\mathrm{P} \text { value from } \\
\text { overid test }\end{array}$ & .40 & .53 & .68 & .50 & .50 & .49 & .04 \\
\hline
\end{tabular}

T-statistics below coefficient estimates. Exogenous instruments for aid include initial year values of per capita income, child mortality, illiteracy and population. 
Table 6

Aid and Economic Freedom index, by decade 2SLS regressions (full sample)

\begin{tabular}{|c|c|c|c|c|}
\hline Equation & 1 & 2 & 3 & 4 \\
\hline Decade & $1980-90$ & \multicolumn{3}{|c|}{$1990-2000$} \\
\hline Constant & $\begin{array}{c}2.17 \\
(4.37)\end{array}$ & $\begin{array}{c}4.33 \\
(1.62)\end{array}$ & $\begin{array}{c}3.66 \\
(6.79)\end{array}$ & $\begin{array}{c}3.59 \\
(6.86)\end{array}$ \\
\hline Initial EF value & $\begin{array}{l}-0.40 \\
(-4.50)\end{array}$ & $\begin{array}{l}-0.80 \\
(-7.90)\end{array}$ & $\begin{array}{l}-0.70 \\
(-8.51)\end{array}$ & $\begin{array}{l}-0.69 \\
(-8.65)\end{array}$ \\
\hline $\begin{array}{l}\text { Avg. annual growth } \\
\text { in per capita income }\end{array}$ & $\begin{array}{c}4.20 \\
(1.33)\end{array}$ & $\begin{array}{r}6.45 \\
(1.94)\end{array}$ & $\begin{array}{c}8.91 \\
(2.95)\end{array}$ & $\begin{array}{l}10.22 \\
(3.43)\end{array}$ \\
\hline $\begin{array}{l}\text { Linguistic } \\
\text { fractionalization }\end{array}$ & $\begin{array}{l}-0.03 \\
(-0.10)\end{array}$ & $\begin{array}{c}-0.26 \\
(-1.04)\end{array}$ & $\begin{array}{l}-0.16 \\
(-0.61)\end{array}$ & $\begin{array}{l}-0.12 \\
(-0.46)\end{array}$ \\
\hline Initial civil liberties & $\begin{array}{c}0.08 \\
(1.07)\end{array}$ & $\begin{array}{c}0.19 \\
(3.02)\end{array}$ & $\begin{array}{c}0.20 \\
(2.95)\end{array}$ & $\begin{array}{c}0.17 \\
(2.66)\end{array}$ \\
\hline $\begin{array}{l}\text { Change in civil } \\
\text { liberties }\end{array}$ & $\begin{array}{c}0.07 \\
(0.87)\end{array}$ & $\begin{array}{c}0.14 \\
(1.62)\end{array}$ & $\begin{array}{c}0.18 \\
(2.23)\end{array}$ & $\begin{array}{c}0.13 \\
(1.63)\end{array}$ \\
\hline Aid & $\begin{array}{l}-0.05 \\
(-3.17)\end{array}$ & $\begin{array}{l}-0.02 \\
(-1.25)\end{array}$ & $\begin{array}{l}-0.01 \\
(-0.41)\end{array}$ & $\begin{array}{c}0.00 \\
(0.20)\end{array}$ \\
\hline $\begin{array}{l}\text { EU accession } \\
\text { dummy }\end{array}$ & & & & $\begin{array}{c}0.66 \\
(2.28)\end{array}$ \\
\hline $\mathrm{N}$ & 76 & 76 & 89 & 89 \\
\hline Mean, dep. var. & 0.17 & 0.85 & 0.89 & 0.89 \\
\hline Std. error of est. & 0.69 & 0.63 & 0.70 & 0.68 \\
\hline $\begin{array}{l}\mathrm{P} \text { value from overid } \\
\text { test }\end{array}$ & .14 & .37 & .08 & .15 \\
\hline
\end{tabular}

T-statistics below coefficient estimates. Exogenous instruments for aid include initialyear values of per capita income, child mortality, illiteracy and population. 


\title{
Appendix 1: Areas and Components of the Economic Freedom Index
}

\author{
Area 1: Size of Government: Expenditures, Taxes, and Enterprises \\ Component A. General government consumption spending as a percentage of total consumption \\ Component B. Transfers and subsidies as a percentage of GDP \\ Component C. Government enterprises and investment as a percentage of GDP \\ Component D. Top marginal tax rate (and income threshold to which it applies) \\ Subcomponent i. Top marginal income tax rate (and income threshold at which it applies) \\ applies) \\ Subcomponent ii. Top marginal income and payroll tax rate (and income threshold at which it
}

Area 2: Legal Structure and Security of Property Rights

Component A. Judicial independence: the judiciary is independent and not subject to interference by the government or parties in disputes

Component B. Impartial courts: A trusted legal framework exists for private businesses to challenge the legality of government actions or regulation

Component C. Protection of intellectual property

Component D. Military interference in rule of law and the political process

Component E. Integrity of the legal system

Area 3: Access to Sound Money

Component A. Average annual growth of the money supply in the last five years minus average

annual growth of real GDP in the last ten years

Component B. Standard inflation variability in the last five years

Component C. Recent inflation rate

Component D. Freedom to own foreign currency bank accounts domestically and abroad

Area 4: Freedom to Exchange with Foreigners

Component A. Taxes on international trade

Subcomponent i. Revenue from taxes on international trade as a percentage of exports plus imports

Subcomponent ii. Mean tariff rate

Subcomponent iii. Standard deviation of tariff rates

Component B. Regulatory trade barriers

Subcomponent i. Hidden import barriers: No barriers other than published tariffs and quotas

Subcomponent ii. Costs of importing: the combined effect of import tariffs, license fees, bank fees, and the time required for administrative red-tape

Component C. Actual size of trade sector compared to expected size

Component D. Difference between official exchange rate and black market rate

Component E. International capital market controls markets

Subcomponent i. Access of citizens to foreign capital markets and foreign access to domestic capital

Subcomponent ii. Restrictions on the freedom of citizens to engage in capital market exchange with foreigners-index of capital controls among 13 IMF categories

Area 5: Regulation of Credit, Labor, and Business

Component A. Credit Market Regulations

Subcomponent i. Ownership of banks: percentage of deposits held in privately owned banks

Subcomponent ii. Competition: domestic banks face competition from foreign banks

Subcomponent iii. Extension of credit: percentage of credit extended to private sector

Subcomponent iv. Avoidance of interest rate controls and regulations that lead to negative real interest rates 
Subcomponent $v$. Interest rate controls: interest rate controls on bank deposits and/or loans are freely determined by the market

Component B. Labor Market Regulations

Subcomponent i. Impact of minimum wage: the minimum wage, set by law, has little impact on wages because it is too low or not obeyed

Subcomponent ii. Hiring and firing practices: hiring and firing practices of companies are determined by private contract

Subcomponent iii. Share of labor force whose wages are set by centralized collective bargaining

Subcomponent iv. Unemployment Benefits: the unemployment benefits system preserves the incentive to work

Subcomponent v. Use of conscripts to obtain military personnel

Component C. Business Regulations

Subcomponent i. Price controls: extent to which businesses are free to set their own prices

Subcomponent ii. Administrative conditions and new businesses: administrative procedures are an important obstacle to starting a new business

Subcomponent iii. Time with government bureaucracy: senior management spends a substantial amount of time dealing with government bureaucracy

Subcomponent iv. Starting a new business: starting a new business is generally easy

Subcomponent v. Irregular payments: irregular, additional payments connected with import and export permits, business licenses, exchange controls, tax assessments, police protection, or loan applications are very rare 


\section{Appendix 2}

Aid, 1980-2000

First-stage regression (full sample)

\begin{tabular}{|c|c|c|}
\hline Equation & 1 & 2 \\
\hline Constant & $\begin{array}{l}11.78 \\
(2.14)\end{array}$ & $\begin{array}{l}55.36 \\
(4.65)\end{array}$ \\
\hline Initial $\mathrm{EF}$ value & $\begin{array}{l}-0.14 \\
(-0.15)\end{array}$ & $\begin{array}{c}0.02 \\
(0.03)\end{array}$ \\
\hline $\begin{array}{l}\text { Avg. annual growth } \\
\text { in per capita income }\end{array}$ & $\begin{array}{l}-93.63 \\
(-2.17)\end{array}$ & $\begin{array}{r}-5.00 \\
(-0.13)\end{array}$ \\
\hline $\begin{array}{l}\text { Linguistic } \\
\text { fractionalization }\end{array}$ & $\begin{array}{l}2.53 \\
(0.87)\end{array}$ & $\begin{array}{l}-3.80 \\
(-1.81)\end{array}$ \\
\hline Initial civil liberties & $\begin{array}{l}-1.43 \\
(-1.80)\end{array}$ & $\begin{array}{l}-1.11 \\
(-1.76)\end{array}$ \\
\hline $\begin{array}{l}\text { Change in civil } \\
\text { liberties }\end{array}$ & $\begin{array}{c}0.32 \\
(0.43)\end{array}$ & $\begin{array}{l}-0.30 \\
(-0.53)\end{array}$ \\
\hline $\begin{array}{l}\text { Log initial GDP per } \\
\text { capita }\end{array}$ & & $\begin{array}{l}-5.28 \\
(-4.32)\end{array}$ \\
\hline $\begin{array}{l}\text { Log initial } \\
\text { population }\end{array}$ & & $\begin{array}{l}-2.36 \\
(-5.75)\end{array}$ \\
\hline Initial illiteracy & & $\begin{array}{l}-0.12 \\
(-2.17)\end{array}$ \\
\hline $\begin{array}{l}\text { Initial child } \\
\text { mortality }\end{array}$ & & $\begin{array}{c}0.07 \\
(3.02)\end{array}$ \\
\hline $\mathrm{N}$ & 76 & 76 \\
\hline $\mathrm{R}^{2}$ & .20 & .67 \\
\hline Mean, dep. var. & 6.88 & 6.88 \\
\hline Std. error of est. & 7.68 & 5.08 \\
\hline
\end{tabular}

T-statistics below coefficient estimates. 
Appendix 3: Countries in base sample

\begin{tabular}{|c|c|c|c|}
\hline Country & EF change & initial EF & $\operatorname{aid}(\div \mathrm{GNI})$ \\
\hline Algeria & 0.61 & 3.89 & 0.50 \\
\hline Argentina & 2.83 & 4.35 & 0.09 \\
\hline Bahrain & 0.32 & 7.31 & 2.13 \\
\hline Bangladesh & 1.83 & 3.69 & 5.24 \\
\hline Barbados & 0.06 & 5.66 & 0.53 \\
\hline Belize & 0.35 & 5.82 & 6.58 \\
\hline Benin & 0.49 & 5.17 & 11.24 \\
\hline Bolivia & 2.42 & 4.28 & 8.75 \\
\hline Botswana & 1.56 & 5.46 & 5.50 \\
\hline Brazil & 1.05 & 4.33 & 0.05 \\
\hline Burundi & 1.00 & 4.16 & 17.41 \\
\hline Cameroon & -0.35 & 5.77 & 4.24 \\
\hline Central Afr. Rep. & 0.48 & 4.64 & 14.34 \\
\hline Chad & 1.31 & 4.35 & 13.99 \\
\hline Chile & 2.26 & 5.22 & 0.17 \\
\hline China & 1.57 & 3.93 & 0.42 \\
\hline Colombia & 0.78 & 4.72 & 0.23 \\
\hline Congo, Dem. Rep. & 0.25 & 3.43 & 4.79 \\
\hline Congo, Rep. & 0.14 & 4.76 & 8.30 \\
\hline Costa Rica & 1.44 & 5.82 & 3.02 \\
\hline Cote d'Ivoire & 0.90 & 5.32 & 5.88 \\
\hline Dominican Rep. & 0.87 & 5.89 & 1.47 \\
\hline Ecuador & -0.61 & 5.85 & 0.08 \\
\hline Egypt & 1.98 & 4.68 & 5.63 \\
\hline El Salvador & 3.02 & 4.41 & 6.09 \\
\hline Fiji & 0.51 & 5.64 & 3.06 \\
\hline Gabon & 1.09 & 4.17 & 2.30 \\
\hline Ghana & 2.69 & 2.93 & 8.12 \\
\hline Guatemala & -0.10 & 6.48 & 1.70 \\
\hline Guinea-Bissau & -2.83 & 5.43 & 51.16 \\
\hline Guyana & 2.69 & 3.71 & 19.78 \\
\hline Haiti & 1.14 & 5.26 & 9.98 \\
\hline Honduras & 0.49 & 5.83 & 8.67 \\
\hline India & 0.84 & 5.24 & 0.71 \\
\hline Indonesia & 0.85 & 5.11 & 1.22 \\
\hline Iran & 1.05 & 4.01 & 0.10 \\
\hline Jamaica & 2.68 & 4.24 & 4.35 \\
\hline Jordan & 1.94 & 5.26 & 12.28 \\
\hline Kenya & 1.44 & 5.12 & 8.64 \\
\hline Korea & 1.22 & 5.76 & 0.03 \\
\hline Madagascar & 1.02 & 4.33 & 11.04 \\
\hline Malawi & -0.27 & 4.85 & 21.93 \\
\hline Malaysia & -0.22 & 6.88 & 0.45 \\
\hline Mali & -0.20 & 5.84 & 18.98 \\
\hline Mauritius & 2.12 & 5.28 & 2.45 \\
\hline Mexico & 0.64 & 5.52 & 0.08 \\
\hline Morocco & 1.38 & 4.54 & 3.17 \\
\hline Namibia & 2.30 & 1.7 & 4.88 \\
\hline Nepal & 0.20 & 5.68 & 9.65 \\
\hline Nicaragua & 2.51 & 4.02 & 24.93 \\
\hline Niger & 0.11 & 5.37 & 15.05 \\
\hline Nigeria & 1.51 & 3.87 & 0.59 \\
\hline Oman & 1.35 & 5.85 & 0.82 \\
\hline
\end{tabular}




$\begin{array}{lrrr}\text { Pakistan } & 0.84 & 4.60 & 2.55 \\ \text { Panama } & 1.22 & 5.96 & 0.88 \\ \text { Papua New Guinea } & -0.35 & 6.25 & 10.40 \\ \text { Paraguay } & 0.34 & 6.51 & 1.42 \\ \text { Peru } & 3.04 & 3.78 & 1.34 \\ \text { Philippines } & 1.76 & 5.30 & 1.70 \\ \text { Rwanda } & -0.01 & 5.28 & 20.38 \\ \text { Senegal } & 0.60 & 5.20 & 13.29 \\ \text { Sierra Leone } & 0.55 & 5.05 & 14.40 \\ \text { South Africa } & 1.02 & 5.70 & 0.30 \\ \text { Sri Lanka } & 1.12 & 4.94 & 6.91 \\ \text { Syria } & 0.92 & 4.04 & 4.09 \\ \text { Tanzania } & 0.98 & 4.80 & 19.70 \\ \text { Thailand } & 0.60 & 6.02 & 0.86 \\ \text { Togo } & 0.83 & 4.19 & 12.12 \\ \text { Trinidad \& Tobago } & 1.96 & 5.06 & 0.25 \\ \text { Tunisia } & 1.07 & 4.99 & 2.12 \\ \text { Turkey } & 2.11 & 3.71 & 0.43 \\ \text { Uganda } & 3.45 & 3.16 & 11.66 \\ \text { Uruguay } & 0.60 & 5.88 & 0.29 \\ \text { Venezuela } & -0.80 & 6.56 & 0.05 \\ \text { Zambia } & 1.34 & 5.08 & 20.12 \\ \text { Zimbabwe } & 0.15 & 4.65 & 4.88 \\ & & & \end{array}$




\section{Appendix 4}

Economic Freedom and Growth, 1980-2000

\begin{tabular}{|l|c|}
\hline Constant & $\begin{array}{c}12.96 \\
(4.05)\end{array}$ \\
\hline Log GDP & $\begin{array}{c}-1.97 \\
(-6.91)\end{array}$ \\
\hline Area 1 & $\begin{array}{c}0.83 \\
(3.52)\end{array}$ \\
\hline Area 2 & $\begin{array}{c}0.75 \\
(5.54)\end{array}$ \\
\hline Area 3 & $\begin{array}{c}0.24 \\
(2.53)\end{array}$ \\
\hline Area 4 & $\begin{array}{c}0.06 \\
(0.35)\end{array}$ \\
\hline Area 5 & $\begin{array}{c}-0.94 \\
(-2.48)\end{array}$ \\
\hline N & 51 \\
\hline Mean, dep. var. & 2.16 \\
\hline F-statistic & 27.34 \\
\hline Std. error of est. & 1.28 \\
\hline
\end{tabular}

T-statistics below coefficients. Estimation by Weighted Least Squares. 